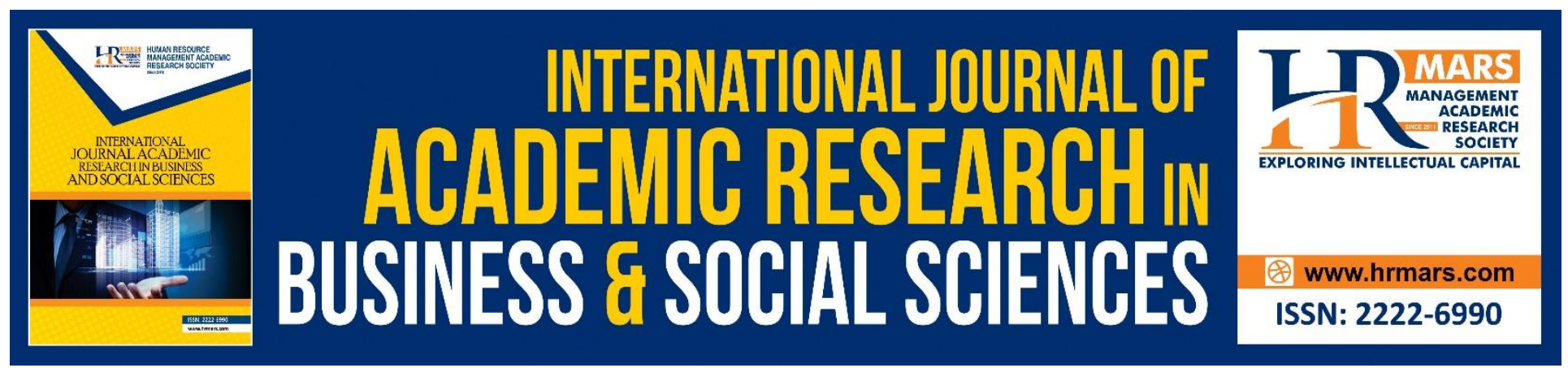

\title{
Triggers and Impact of Habitual Betting Enterprise on Christian Youth in Soweto Village, Nairobi County, Kenya in the Light of Jesus' Liberating Pedagogy
}

P. N. Wachege, Juliet Kadondo Mugalo

To Link this Article: http://dx.doi.org/10.6007/IJARBSS/v9-i2/5593

DOI: $\quad 10.6007 /$ IJARBSS/v9-i2/5593

Received: 03 Feb 2019, Revised: 16 Feb 2019, Accepted: 03 March 2019

Published Online: 06 March 2019

In-Text Citation: (Wachege \& Wachege, 2019)

To Cite this Article: Wachege, P. N., \& Wachege, P. N. (2019). Triggers and Impact of Habitual Betting Enterprise on Christian Youth in Soweto Village, Nairobi County, Kenya in the Light of Jesus' Liberating Pedagogy. International Journal of Academic Research in Business and Social Sciences, 9(2), 579-598.

Copyright: (C) 2019 The Author(s)

Published by Human Resource Management Academic Research Society (www.hrmars.com)

This article is published under the Creative Commons Attribution (CC BY 4.0) license. Anyone may reproduce, distribute, translate and create derivative works of this article (for both commercial and non-commercial purposes), subject to full attribution to the original publication and authors. The full terms of this license may be seen at: http://creativecommons.org/licences/by/4.0/legalcode

Vol. 9, No. 2, 2019, Pg. 579 - 598

Full Terms \& Conditions of access and use can be found at http://hrmars.com/index.php/pages/detail/publication-ethics 


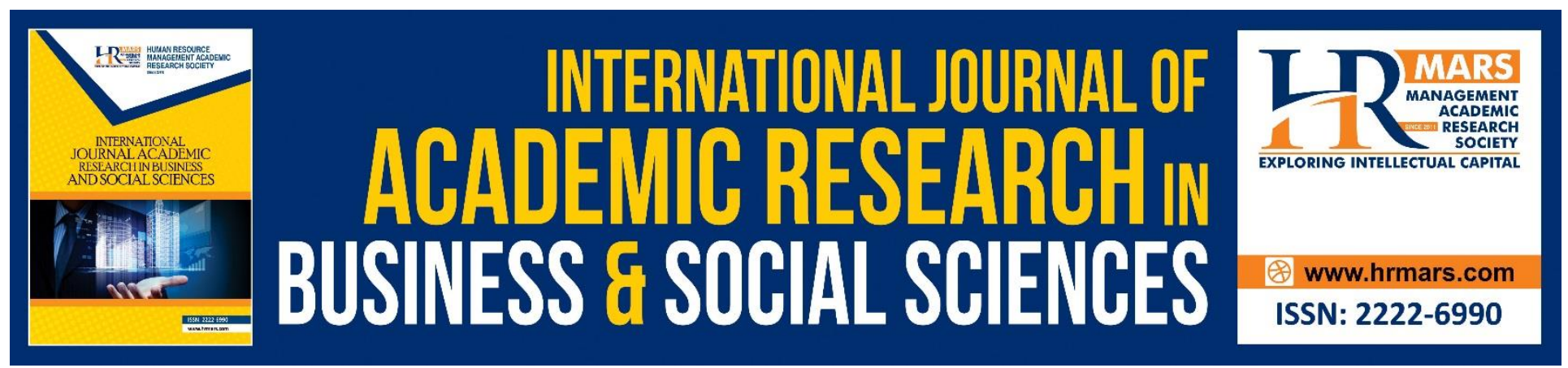

\title{
Triggers and Impact of Habitual Betting Enterprise on Christian Youth in Soweto Village, Nairobi County, Kenya in the Light of Jesus' Liberating Pedagogy
}

\author{
Prof. P. N. Wachege \\ Department of Philosophy and Religious Studies, University of Nairobi, Kenya \\ Nairobi, Kenya \\ Email: patricknwachege@gmail.com
}

Juliet Kadondo Mugalo

University of Nairobi, Kenya, Department of Philosophy and Religious Studies, University of Nairobi, Kenya

Email: juliet.kadondo@gmail.com

\begin{abstract}
The study is on the triggers and impact of habitual betting enterprise among Christian youth in the light of Jesus' liberating pedagogy in Soweto Village in Nairobi County, Kenya. The main goal is to investigate the causes and effects of addictive betting engagement among Christian youth in Soweto Village illumined by Jesus' liberating pedagogy while interrogating the agents of Christianity in the realization of Christ's mandate to minister to all in collaboration with Him. Three specific objectives that guided the study were: To identify the triggers of habitual betting among Christian youth; to establish the effects of habitual betting among Christian youth; and to examine the role of the Church, under the inspiration of Jesus' liberating pedagogy, in curbing addictive betting enterprise among the aforementioned youths. The study engaged descriptive survey research. Purposive sampling was used to select the sample of forty Christian youth, ten parents, seven administrators, police officers and the area chief, and three clergy. Questionnaires and structured interviews were used to gather primary data while secondary data was drawn from various relevant sources. Data was analysed through descriptive analysis. Three complementary theories guided the Research to accomplish its goal. These are: Self-efficacy theory by Bandura; mediation theory by Boff and Boff; and self-regulatory theory by Leventhal et al. The study found out that there are various critical factors that contribute to the habitual betting among the Christian youth in Soweto Village that include unemployment, advertisements, peer pressure, early exposure to betting and as an escape from reality. Some of the effects of habitual betting among the above youth the Research found out are; betting addiction, early
\end{abstract}


school dropout, family disruptions, job loss, suicide thoughts, rising debt level and development of criminal behaviour together with premature deaths. The Church in Soweto has made some effort, though inadequate, to provide the Christian youth with some activities like sports that will help them to feel as part of the entire "Family of God." Through organizing some seminars and youth fora they are helped to showcase their talents and capabilities thus diverting their attention from habitual betting. The unfortunate thing is that there are different interpretations of Scripture by the different local Churches on whether a Christian should engage in betting or not on the one hand. On the other hand, these evangelizers do not seem to take Jesus' liberating pedagogy with the seriousness it deserves thus doing injustice to Christ's principle of "without me you can do nothing" (Jn 15:4) as they undermine Christ's teaching on living full (Jn 10:10), not just existing, and pragmatically taking Him as the Way to True Life (Jn 14:6) - hence the need for the Research to educate and provoke such awareness.

Keywords: Betting Enterprise, Christian Youth, Jesus' liberating pedagogy, Conscientization, Trust in Life

\section{Background}

Although gambling is illegal for young people, the great proportion of individuals growing up today is likely to have direct experience of gambling before they reach 18 years (Ton, 2013:5). Gambling is wide with betting being part of it which has become apparently the in-thing in Soweto Village, Nairobi County Kenya. With the scenario comes addiction to the enterprise that compels the Research to find out the triggers of habitual betting and also to investigate the arising negative consequences thereby. It is also provoked to interrogate the role Christian agents of evangelizing are playing as they minister to the youth in Soweto and whether their effort can be more significant if they dispose themselves to Jesus' liberating pedagogy.

According to Collins, gambling is an activity through which parties risk something valuable referred to as stake with the expectancy of winning a more valuable prize (Collins, 2003). As such, betting refers to an act that one should put some pledge so as to get something more valuable. In several cases, money is used for a stake hoping to win; there is the options of win lose or draw. A possible explanation for adolescents in lower SES gambling more excessively could be due to their perception of gambling as a practical means of improving their financial status (Welte, Barnes, Wieczorek, Tidwell, \& Parker, 18, 313-337(2002). Africa is not an exception to this phenomenon. Betting has flourished in different countries driven by increasing evidence of betting promotions and advertisements among other triggers. South Africa, Nigeria and Kenya are among the countries with the largest and the fastest growing betting markets in Africa. In 1980s, the gambling market in Sweden was commercialized by allowing gambling companies promote and market their games as opposed to the earlier position where advertising was not allowed. Examples of games in gambling include lotteries, casino games, poker, bingo, and Electronic Gambling Machines (E.G.M.s.) (Korn and Shaffer, 1999:289-365). As a consequence gambling market expanded with regard to games, game avenues, and arenas and marketing. Electronic gaming machines which were withdrawn in the 1970's due to social problems, were re-introduced in the 1996 and in the beginning of the $21^{\text {st }}$ century, there were four internal state owned casinos. This is useful information although our Research focuses on habitual betting enterprise in Kenyan among the Christian youth in Soweto Village as a case study. 
Betting in Kenya was an illegal enterprise until 1954 when a committee was formed to look into matters pertaining to controlling gaming and betting activities. The committee was also responsible for looking into the existing laws and practice of gambling, betting, and lotteries and report on changes that needed to be made. The committee submitted a report to the government on its findings in December 1953 and the report was accepted in September 1954. In 1963 the government introduced the Betting Tax Ordinance to tax bets on horse racing. Betting, Gambling and Lotteries Bill was presented to the Parliament and was passed and then revised in 1991. In Kenya the larger percentage of the gamblers are those who engage in sports betting and the youth make the larger portion of the betters, and today the Christian youth of are no exception.

Based on our Biblical sourcing we come to learn that one of the basic Christian principles is that Jesus in His liberating teaching propagated the pedagogy of having come so that all may have life and live in abundance (John 10:10) and that He is the Way, the Truth and the Life consequently the Way leading to True Life (Jn 14: 6). Still the youth's life, more so those of Soweto Village, can hardly qualify to be living fully despite being Christ followers. Neither can the betting addiction path some of them are getting hooked to can hardly be qualified as way to true life propagated by the one whose disciples they are. With the above in mind, the Research is timely as a study on the triggers and impact of habitual betting enterprise among Christian youth in the light of Jesus' liberating pedagogy in Soweto Village in Nairobi County, Kenya. To accomplish the finality, the Research utilized three interrelated theories in the endeavour. These are: self-efficacy theory by Bandura; mediation theory by Leonardo Boff and Clodovis Boff; and self-regulatory theory by Leventhal et al. At this stage, clarity of the key concepts utilized in the research is important: The term betting is operationalized as the action of gambling money on an outcome of a race, game or other predictable events (Oxford Dictionary; 2018) and may also be utilized to refer to Gambling or gaming. Youth is a person who has reached the age of 18 years and has not attained 35 years (The Kenya Constitution 2010: Article 55). For pragmatic purposes, the research uses the concept to refer to the young people aged 15-35. As such, qualifying it as Christian youth signifies the category of the above youngsters whose faith affiliation is that of Christianity thereby guided, guarded and inspired by the principles and standards of Jesus Christ the Saviour/Redeemer also given the attribute Liberating Teacher par excellence. With regard to Conscientization it conveys the perception of creating awareness assisting in figuring out how to see social, political and monetary inconsistencies and to make a move against the oppressive components of the real world (Freire, 1998:41ff).

\section{Problem Statement and Fundamental Guiding Questions}

Betting is a phenomenon that has enhanced problems to society and is growing at a disturbing rate. What is even more worrying is that youth are getting engaged in it much more than the rest of the population. Worse still, more and more Christian youth are becoming habitual betting victims making one wonder whether Christian values, mainly those of Jesus' liberating pedagogy, have become obsolete.

From Scriptural foundation disciples and followers of Jesus, and especially the ordained ministers, are supposed to adhere to the standards of Jesus in His liberating teaching of having life and living it fully (John 10:10) and taking after Him as their Way, their Truth and their Life consequently the Way to True Life (Jn 14: 6). Still the youth's life, more so those of Soweto Village, are surviving as victims 
of betting addiction hardly then qualifying as living fully or even following liberating Jesus' true way to life despite being Christ followers and still the Church is mandated to minister to them. Such a scenario became a real issue for this research.

As such, the study endeavoured to look into the reasons behind Soweto Village Christian youth engage in habitual betting and its impact on their lives wondering whether understanding and utilizing Jesus' liberating pedagogy will go a long way in curbing the disturbing vice.

The following research questions guided the research:

1) What are the triggers that make Christian youth habitually engage in the betting enterprise?

2) What are the effects of habitual betting among the Christian Youth?

3) How does the Church help in curbing this habitual phenomenon among the Christian youth in the light of Jesus' liberating pedagogy?

\section{Objectives, Hypotheses and Rationale}

The main goal of the research was to investigate the genesis and impact of habitual betting enterprise on Christian youth in Soweto Village, Nairobi County, Kenya in the light of Jesus' liberating pedagogy. In the endeavor, it was guided by the following specific objectives:

1) To identify the triggers of habitual betting among Christian youths.

2) To establish the effects of habitual betting among Christian Youths.

3) To examine the role of the Church in curbing habitual betting phenomenon among the Christian Youth in the light of Jesus' liberating pedagogy.

These threefold finalities are hypothesized as follows:

1) There are triggers that make Christian youth engage in habitual betting practices.

2) There are effects of habitual betting among Christian youth.

3) The Church can play a better role of curbing habitual betting among the Christian youth in Soweto Village, Nairobi County, Kenya if it draws inspiration and guidance from Jesus' liberating pedagogy.

Soweto Village is found in the Soweto area of Nairobi and its population is mainly poor and found in informal settlements. The people are mainly involved in casual labour and therefore it is difficult for some of the residents to afford a day's meal. Christians are part of the population; they too feel the consequence of abject poverty that characterizes the locality. The Village youth belong to several Christian denominations. Some attend Church services or sacrifices of Mass, but afterwards they go to their betting habits thus returning home the way they came unchanged. Betting has become an enterprise that these Christian youth cherish more than the preaching in their Churches making the Research wonder: What do they get in the betting enterprise that is not found in their respective Churches? Despite the reality that the Soweto Christian youths are besieged by poverty, still they are the future of society and they need to be well formed in character to take up their leadership roles. In the Village, there are various betting promotion advertisements and numerous betting joints with a huge number of youths bearing Christian names as committed customers. One only needs to visit the area to confirm the assertion. The temptation of participating in gambling is evident since the Christian youth experience it directly from the media adverts, easy and accessible internet technology and digitization of gambling. In the sale promotions inviting participation, between 35 and 40 percent of the participants are youth. Out of the estimated 1,500 people who gamble every day in Kenya's 36 
operating casinos, nearly 25 percent of them are aged between 25 and 35 . Masonko wa Safaricom promotion is one example where 38 percent of those who participated were the youth, indeed the top prize of KShs 25 million was won by a twenty five year old. (Wanjohi, 2012:5). A cross survey of most of the winners revealed that they were not employed and were actually entering the lotteries and promotions to earn a living. This therefore makes it a major issue of concern not only to the Government but also the society (Ibid., 3). The study was entirely confined to the Christian youth aged 15-35 years, the clergy, parents and the administration officers in getting the required information. The youth in the targeted bracket are in the period of identity formal cognitive development and preparation for the future adult life in terms of education, work and finances (Arnett, 2000:469-480).

\section{Literature Review}

Research among youth in age range of about 20 to 25 years has often been conducted in samples of college students. Two analyses of international studies found out that the prevalence of the problem among college students was 7.9\% in studies until 2005 (Blinn-Pike, Worthy and Johnman, 2007:175-183). Turner and Colleges revealed gambling involvement increased with age from $39 \%$ in $5^{\text {th }}$ grade to $65 \%$ in $7^{\text {th }}$ grade, $80 \%$ in $9^{\text {th }}$ grade, and $83 \%$ in $11^{\text {th }}$ grade (Turner, Spence and Zangerah, 2008:281-298). In comparison to females, male youth tend to gamble more often, begin gambling at an early age, spent more time, fell more to gambling and experienced more gambling problems (Jacobs, 2000:119-152).These findings that the male youth is more prone to such problems, is confirmed by Wachege and Rũgendo in their study titled "Factors leading to premature deaths of male youths: A case of Karũri Catholic Parish Kenya" (Wachege and Rũgendo, 2017:64-74). While the above is enriching, the current study investigated both male and female Christian youth involved in betting.

Gupta and Derevensky provide very interesting ideas on the subject (Gupta and Derevensky, 1998:319-345). They found out that teenagers felt betting is an approach to mingle, influence companions, to unwind, ease weariness, feel more established, escape day to day issues, lighten discouragement, and manage dejection. They are elaborate that betting is progressively getting to be standardized in the public eye, inordinate youth betting has been understood as dangerous, similar to misconduct, since it has possibly negative results, for example, fixation, truancy, poor scholastic evaluations and robbery. They explain that betting transports neurotic players to a dreamland without life's day to day issues, uneasiness, wretchedness and depression. This inspired the study in investigating the particular triggers and effects of habitual betting among the Christian youth in Soweto Village though the above is not elaborate in drawing out the triggers and specific impacts to the addictive enterprise.

Blinn-Pike et al. (2007:175-183) are of the view that young people do engage in gambling in order to get solace to the contemporary problems and existential challenges. They think that if they do get engaged to the enterprise they will get more than they can ever think, a reality the young people cannot comprehend. While the research, Blinn-Pike et al do not help much in providing a role model who is exemplary in showing the way forward in a liberational manner. This is where Sobrino comes in handy in his book titled, Jesus the Liberator: A Historical-Theological Reading of Jesus of Nazareth (Sobrino, 1999:1ff). The author explains the perception and value of liberation in the context of Jesus 
Christ as the absolute exemplar in liberating teachings from all kinds of enslaving evil and restoring the required human authenticity that guarantees realization of one's potentialities and living life abundantly while maintaining the realm of salvation. He accentuates the ongoing dehumanizing characteristics that are incompatible with the Good News and repugnant to Christianity that often times escapes the attention of the carriers and exponents of the Gospel whose bottom-line is to embrace God's benevolent talents utilizing them towards informed freedom, living one's life fully and following the redemption path to true life (Ibid., pp.3ff). His work is useful in employing Christology geared towards Christ's liberating pedagogy geared towards emancipating people from the yoke of what habitually keep them in captivity making them live in a way they ought not to. The book, nevertheless, does not actually concretize these good ideas as the study does for specificity sake.

Freire's monograph namely "Education for Critical Consciousness" assists us in the conscientization of what is happening in the society thereby challenging us to work towards social and cultural freedom (Freire, 1994:p.vii). He spells out the indispensability of education in any emancipation engagement even that of the youth (Freire, 1994: p.7). Moreover, in his other publication titled Pedagogy of Hope (Freire,1992: 13ff) optimism is asserted despite dirty manipulations and other forms of exploitation and oppression some propagated by leaders instilling desperation for not getting involved in eliminating such unfortunate factors. While the ideas are no doubt very helpful for the research, yet the author does not handle the issue of giving the youth hope in their tempting situations in life and creating optimism that they have the capability of freeing themselves from the yoke of, for example, habitual betting that is ruining them. A notable shortcoming of the foregoing literature is the omission of substantial Scriptural base of the research's subject. The gap is filled by resulting to Biblical foundation utilizing scriptural relevant texts, rationale behind attributing the title Teacher and pedagogical Liberator to Jesus as explicated by scholars like Sean Kealy and Joachim Jeremias.

It is of immense importance to appreciate that Jesus' liberating pedagogy has a strong biblical rooting. In His liberating pedagogy, Jesus the Teacher - an attribute persuasively justified by Kealy (2001) - is outstanding in His profound instruction significant in curbing habitual betting especially among the youth employing original monumental stories each imbued with a particular edifying message that transforms towards authentic living in genuine free. Such profound educating stories are technically called parables which are adequately explained by Jeremias in his monumental works titled The Parables of Jesus (Jeremias,1972) and Rediscovering the Parables (Jeremias,1966). Among the striking ones significant to the research are: that of the prodigal son (read also prodigal daughter) in Luke 15:11-32. Here the youth squandered the inheritance with luxurious hedonism which perhaps included wasteful addictive betting while the other child rebelled against the father for welcoming the stray one with exaggerated conviviality marking both a repentant return and a welcome homecoming and re-incorporation into the family. The other parable is that of the rich spendthrift (Lk 16: 19-21) whereby the tycoon swallowed up in self-satisfaction cum glorifying power foolishly made money and wealth his gods assuming that he is not contingent only to realize how fickle material things are and that mortality comes to all irrespective of social status. We the have the parable of the barren fig tree (Lk 13: 6-9. Here, fruitfulness is promoted while un-productiveness is discarded. Then there is the juicy parable of the talents (Mt 25:14-30; Lk 19:11-27) in which appreciation and meaningful utilizations of God-given charisms is rewarded whereas undermining or 
taking one's gifts for granted is condemned. There is also that of the lost sheep (Lk 15:4-7; Mt 18:1214) signifying that God is a loving understanding parent who readily goes out to patiently seek and incorporate the lost into the family without demanding retribution or undue humiliating humility in expressing one's repentance. We further have the parable of the labourers in the vineyard (Mt 20:16) whereby even those who accepted the invitation to be employed in the vineyard, opting out of the comfort of idling, in the eleventh hour are the first to be remunerated at the end of the day and their salary equated with that of those employed earlier to the envy of the latter. In addition, there is the parable of the seed growing by itself (Mk 4: 26-29) teaching even the youth that disposing oneself well to the kernel of the Good News and making effort in life and living will result in amazing growth, realization of one's potentialities and accomplishment of authentic ideals. More pedagogical Scriptural pericopes and Biblical block passages can be drawn but the above are adequate for the subject matter.

This liberating Teacher who pitched camp among us as Jesus of Nazareth (Jn 1:14) identifies Himself with the way to true life, or rather, true way to life (Jn 14: 1-4). He makes it explicit that His fundamental option is to make us have life and have it abundantly (Jn 10:10) as He commands us to love one another (Jn 13: 34-35) such that we guard against exploitative betting imbued with negative manipulations. As such, $\mathrm{He}$ is best qualified to challenge Soweto youth and others that they ought to live fully and authentically since He reveals that such is the fundamental option geared towards enabling people to embrace life thereby living fully in His ministry and those He chooses and delegates to be Him to them. He is, moreover, the liberating Teacher who is honest in disclosing to us, youth included, that in the world we will encounter problems but we should not worry un-duly since He has exemplified to us that we will take after Him in overcoming troubles and cropping up disturbing issues if we live by His standards and benevolent support (Jn16: 33). Such is the liberating pedagogy well concretized in, for instance, resurrecting Lazarus the brother of Martha and Marry of Bethany ( Jn 11: 1ff), the son of the widow of Naim (Lk 7: 11-17) and raised an official's daughter to life (Mt 9:23-26), restoring sight to two blind ones to help them have a better vision of life (Mt 9: 27$31,32-34)$, cured a woman who suffered the embarrassment of haemorrhage that blocked her from living fully (Mt 9: 20-22), healed the ten lepers who were cut off from the community because of the dreaded disease analogically "their HIV/AIDS"(Lk 17:11-19) and even sent not just the 12 Apostles to minister but also 70/72 others (Lk 10:1ff) thereby expressing a strong desire to have the ordained priests collaborate in shepherding with the common pastors namely the laity who include Soweto Christian youth to be ministers also unto themselves too.

Moltmann is quite informative on the issue of instilling hope even in problematic concrete situations in life - in our case, that of habitual betting. In his book namely The Theology of Hope in 1964 (Moltmann, 1964: pp.1ff), the author discusses the issue drawing out hope even in the scandal of being crucified for a just cause. In this regard, he is more explicit and, indeed, elaborates in his other work titled The Crucified God (1974). The scholar explains that the death of Christ is not only redemptive. It is also intended to empower us with means to overcome sin "the root cause of unfreedom" (Wachege, 2002: 272-302). In this regard sin is viewed as the core of dehumanization which requires of our effort to overcome the factors that make us live in a manner we are not supposed to live. It offers also an awareness of exclusiveness and vicious circle of poverty in the contemporary society which urgently needs to be overcome (Moltmann, 1974: p. 331). Much as these 
insights are valuable, the author does not, nevertheless, directly address the youth as the recipients of the above. This is a gap the study chips in to fill.

Another scholar the study benefits from is Boesak. Although his book is on South African black power theology of liberation (Boesak, 1977), nonetheless, it helps the study to draw out the way forward in the sense of strongly recommending to the Soweto Christian youths to emancipate themselves from a naive approach to life, assert themselves as special people who are made in the likeness of the Maker thereby not undermining the self-esteem and genuine assertiveness. It also assists the study in explaining that: "The search for authentic and credible human personality and freedom is likewise to recognize that one's Africanness is a natural gift to thoroughly enjoy as opposed to a destiny to be bemoaned"(Ibid., p.40). In addition, Boesak's work helps us to be proud of, appreciate and assert our African values as he encourages even the youth to live their lives and not let others live their lives for them. This should help the youths to accept and be proud of themselves as individuals gifted with respective identity, worthy culture as well as the gifts and talents to excel if they strive to live a disciplined life-style while refraining from gambling their lives by being psyched to get quick riches and wealth through commercialized manipulated betting. The limitation is that Boesak's book is mostly based on apartheid South Africa in their experience of colour bar, structures of injustice, racial oppression and exploitation while ours is situated in independent Kenya whose youths in a way have freedom of choice, some of which may not be moral decisions.

Bujo highlights the understanding and acceptance of moral norms by all within the community (Bujo, 1998: pp. 130ff). While addressing the suffering and poverty in the Third World, he raises the question of a possibility and reality of suffering when God is supposed to be merciful. He brought out the parallels between the Latin American poverty and social - economic challenges and the African oppression, poverty and exploitation thereby proposing a theology of liberation as a crucial mode of theologizing that identifies and helps in transforming oppressive factors ( Ibid., pp. 132ff). The study intends to embrace liberation of the challenged gambling Christian youth of Soweto Village and specifically liberation brought about by Jesus' redemptive pedagogy, an undertaking that Cone supports.

Cone, in his monograph God of the Oppressed (Cone, 2002) based on the oppression of the African Americans expresses the desire for the liberation and freedom of the black person from oppressive and enslaving elements such as lack of acceptance or recognition. They look up to the Gospel to bring them liberation and that through the same there is hope for a better life in future. Though Cone does not specifically deal with the aforementioned problems encountered by Soweto Christian youth, the study finds his work insightful as it moves ahead in assisting the youth to tackle habitual betting problem, among others, in the light of Christian message of living life fully. Yet, there is the lacuna of not revealing the complexity of life and the scenario of losing trust in life. Kung chips in to feel the gap.

In his book titled What I Believe (Kung, 2010), Kung explains that though life is no doubt complex and occasionally troublesome, one should not lose trust in it. As the author observes, "One can live through tribulations and disappointments by constantly standing firm and then taking new steps. This is a primal trust which in the face of all the attacks of frustration and despair becomes a lasting hope. In this way one can practise the virtue of perseverantia, of holding fast, of persistent, of endurance" (Ibid., pp. 12-13). He explains that such basic trust in life - implying that it is worthy living to use 
Fulton J, Sheen's coinage - is both the pillar of one's identity as well as an ongoing entity. That is why Soweto Christian youth, and others, enslaved in betting enterprise need to realize that: "Fundamental trust is the foundation of a sense of identity, but it has to be maintained in endlessly new ways through all social and psychological conflicts."(Ibid., p. 14). As such, fundamental trust remains a lifelong task that has to be given constantly. It should also be realized that human relationality is interwoven with trust although uncritical trust is not good. Actually, as Kung explains, "in all trust in life, wisdom about life, is also required - the applied power of judgement, a balance between trust and justified reservations, in the individual case also between scepticism and mistrust" (Ibid., p. 15). As a consequence of the above, joyful life is generated that makes one acquire truly happy and inner genuine peace that enhances living in freedom. This does not, nevertheless, mean that the aforementioned youth should embrace the popular maxim that "the main thing for me is to be happy" uncritically. In this regard, Kung further observes that there is need to interrogate it realistically with the rationale that, "Hedonistic enjoyment of life is all too often disappointing, and even the most refined enjoyers of life sooner or later get in a situation where the 'fun' ceases and all satisfaction is at an end" (Ibid., p. 20). Of even greater significance to Soweto Christian youth more so those in great demand of emancipation from habitual betting enterprise is the realization that: "Lasting joy in life is not expressed in the statement 'I am happy' but in the statement 'I am in harmony with myself, sorted out, satisfied'"(Ibid., p.20). Consequently, the youth should develop awareness that even the captivating euphoria, actually eureka, of "nimeshinda!" (I have won) could as well be fickle and deceptive giving the recipient relative superficial happiness without joy.

As for Kinoti, with the coming of Christianity, Church discipline was in a way supposed to replace the traditional moral system that was followed and respected by the Africans but failed to do so thereby creating a moral vacuum (Kinoti, 2013:p.15). The author therefore views the moral problem that is rampant with the young people today as a result of both the failure of the social system and the Church, and as such both are duty bound to be part of the solution. On social system, Getui contributes and asserts that the value of self-discipline should be inculcated into young people right from early age by letting them express themselves freely and initiate their own creativity but with guidance and making them follow laid down rules (Getui, 1998:71-84). Teaching on self-discipline should also include inculcating the value of hard-work into everyone without exception, whether male or female youth as Wachege and Rũgendo posit (Wachege and Rũgendo, 2017: 691-711).

\section{Underpinning Theories}

The study was guided by three inter-related theories to accomplish its goal. These are: self-efficacy theory by Bandura; Mediation theory by Leonardo Boff and Clodovis Boff and self-regulatory theory by Leventhal et al. The self-efficacy theory states that human conduct is impacted by the degree to which an individual trusts that he has the capacity or skill to attempt certain conduct (Bandura, 1980). Thus Christian Soweto youth should arise and belief in something much more than gambling to bring them out of the economic situation they find themselves in. According to Bandura, people underestimate their capabilities and this is what the youth have exactly done. The theory also asserts that capability does not have to be based on skills and educational background (Artino, ED499094.pdf). 
The Christian youth have to feel that they are capable of doing the will of God by working just as He (God) ordered. They must ensure that they use the God-given talents and gifts by bringing their creativity into action. They should feel some kind of freedom since they will be eating what they worked for rather than waiting on bet that they are not sure if they will win or not. Jesus Christ is an example that they need to emulate since $\mathrm{He}$ is the liberator who instructed everyone to love work. They should strive to use their potentialities to enable them be liberated in the society where they are looked upon as the providers of the necessary needs to their families.

Mediation Theory has two Latin American brothers as its exponents who are of international repute in Christian Liberation Approach to theology. These are Leonardo Boff and Clodovis Boff who coauthored a book named Introducing Liberation Theology (Boff and Boff, 1987:24-39). In his book we draw a very helpful method of accomplishing our aforementioned research. The theory gives three major moments for a worthwhile involvement in a liberating theology which is Christian namely: Socio-analytical aspect (Ibid., pp.24-32); Hermeneutical aspect (Ibid., pp.32-39); and praxis also referred to as pastoral moment (Ibid., pp.39-41). The Social-analytical mediation assisted the researcher to insert self into the situation of the Christian youth in Soweto so as to get first-hand information on why they are becoming habitual betting culprits. Hermeneutical mediation was utilized in relating the data acquired in the first moment to the will of God as found in the Bible, Tradition and theologians' insights. It was an engagement that was used in interpreting the findings in the above stage that provided the actual socio-religio-political, cultural and economic factors involved in luring the youth to the habit of betting despite the frustrations they go through. The pastoral or praxis mediation inspired the research to come up with a transforming way-forward as the contribution of the study.

The other theory that was utilized is self-regulatory theory by Leventhal et al (Leventhal, Safer and Pangais, 1983) which states that people are generally motivated to regulate their behaviour to avoid engagement in a deviant behaviour and, that they actively extract information from their environment and previous experience to formulate plans and actions to cope with drives that lead to delinquency behaviour. They should be educated on various drives that make them engage in delinquency behaviour like gambling. The awareness on such issues will make them be able to cope with them so as not to plunge into problems that are associated with gambling. The theory is important to this study for practical recommendations and way forward.

\section{Research Methodology}

This section dwells on the methods used to conduct the study, the population and sample selection, research design, data collection technique and data analysis techniques.

\section{Research Design}

The study is a qualitative one and the case study research design was engaged in an endeavour to find out the impact of habitual betting enterprise among Christian youth of Soweto Village. Such a case study of Soweto Village was relevant to enable in-depth investigation into the issue. The qualitative descriptive research was employed by the study. The descriptive survey used was useful in describing the features of the population. The design was esteemed reasonable since it portrays the situation as they exist without control of factors (Nsubaga, 2000). 


\section{Population and Sample Selection}

The target population for this study comprised the Christian community from Soweto slum, who are the Christian youth, the clergy, parents and the administrators. The study targeted sixty respondents. Purposive sampling was applied to identify the relevant respondents. Forty Christian youth, ten parents, seven administrators and three clergy from three different Churches in Soweto Village.

\section{Data Collection Techniques}

The data was collected from primary and secondary sources. The primary data was sourced through questionnaires and structured interviews which were administered to the study respondents while the secondary data was sourced from books, the internet, academic theses, articles and the journals. The collected data was arranged into manageable summary then helped the researcher fill the gaps identified bearing in mind the research objectives.

\section{Questionnaires}

The questionnaires included both open ended and closed ended questions that the respondents answered. Questionnaires were used because they are useful when there is need of a large number of standardized responses that need to be compared; they ensure more uniformity since the questions are already written down and the respondents feel free and confident to express themselves (Wambua, 2018). The questionnaires were administered to the Christian youth, the clergy, the parents and the administrators in the Soweto Village. They were hand delivered to the respondents by both the researcher and the research assistant who had earlier been identified and trained.

\section{Data Analysis Techniques}

Since the study targeted qualitative data, the descriptive method was used to process the data collected. The results were compared with the literature review to examine the role of the Church in curbing habitual betting among Christian youth bearing in mind the objectives of the study. The qualitative technique used enabled methodical accumulation, analysis and interpretation of data to provide descriptive accounts of social events and objectives in a natural setting ( Kombo and Tromp, 2006).

\section{Ethical Considerations}

While conducting the research, care was taken to ensure confidentiality and anonymity. The researcher first, sought consent from the respondents before gathering data whether in the form of interviews or through administering questionnaires. The research ensured confidentiality and anonymity of the respondents by not using their names on the instruments unless in circumstances where they give written and signed consent. To help them feel free to complete the information and give their sincere information (Orodho, 2009), their respective personal identity was protected (Mugenda and Mugenda, 2010). Participation in the study was thus optional. The researcher also endeavoured not to cause any harm to the respondents and ensure their dignity was maintained at all times. 
INTERNATIONAL JOURNAL OF ACADEMIC RESEARCH IN BUSINESS AND SOCIAL SCIENCES

Vol. 9, No. 2, Feb, 2019, E-ISSN: 2222-6990 C 2019 HRMARS

Findings, Implications, Recommendations and Conclusion

The Research's findings, implications, recommendations and conclusion are as follows:

\section{Findings:}

1) There are triggers that make Christian youth engage in habitual betting practices. The ones the Research came up with are: peer pressure, inaction by parents, enticing ubiquitous advertisements, in-effecting shepherding manner of evangelizing a diversified "endangered" youth, unemployment together with under-employment, escape from uncomfortable reality, compelling desire to quick richness and wealth, poor coordination of youth programmes both by County and Central governments and meager earning.

2) There are serious effects of habitual betting among Christian youth in Soweto Village, Nairobi County. Among those the Research found out are: family disruptions, development of criminal behaviors, betting addictions, early exposure to betting practices, little or inadequate parental care, early school dropout, loss of job, suicide thoughts and difficulties in clearing outstanding debts.

3) The Church agents of evangelization can play a better role of curbing habitual betting among the Christian youth in Soweto Village, Nairobi County, Kenya if it draws inspiration and guidance from Jesus' Liberating Pedagogy.

4) There is a considerable number of implications of the study which include spiritual implications, pastoral implications and catechetical ones- some of which are spelled out below:

\section{Implications}

Several implications are drawn out of the Research. These are:

1) If betting continues the tendency to produce lazy people in society will keep rising. The outcome of broken and dysfunctional families is real as the effect of the gambling problem causes havoc in families as conflict and misunderstandings manifest.

2) Lack of employment or an authentic means of livelihood will compel youth to look for a way of earning money to meet their daily needs, for entertainment and to match their peers who could be doing well as these are also important things to them. The result may be enhancement of crime in the society and cropping up of more illegal gang groups.

3) High rate of school drop-out implies the youth's life is disempowered to tap into viable economic benefits of being educated. They will be left behind in terms of technology and communication. The aged parents will suffer since their children will not be empowered to cater for their welfare at old age.

4) The Church risks losing her authenticity, relevance and moral authority in a society if she does not diversify her evangelizing methods and if it refrains from mingling with the youth to comprehend their worries, concerns, existential challenges they are confronted with. It is indispensable that the shepherds pay serious attention to the kind of questions the youth are raising in various realms of life and engage them with honesty in responding to them and also in questioning their questions. 
5) Persistent advertisements continue to create the impression in young people that betting is a normal thing to do in life thus leading to dangerous addiction. Thus any impression created by the advertisement at these developmental stages will be hard to reverse.

6) The agent of the Good News should realize that proper evangelization will result in a youth who is well prepared to confront vices and challenges in society. The same applies to the case of second evangelization. When the betting youth escape the truth based on the Scripture which is the basis for this evangelization, then they are already lost. The Church in Soweto has some work cut out in its effort to disseminate this Word in forms the youth can understand, apply and own it.

7) Slavish dependency on the clergy can be limiting in that parents are the first and foremost educators of the child. It is at home where children first learn about Godly virtues like love, charity, patience and obedience among others and existential values.

8) When the youth are empowered they can pull themselves out of the problems confronting them like poverty, peer pressure and bad decisions. Going by the study findings a new pastoral approach is inevitable on this issue. The youth will benefit from a pastoral plan for the family apostolate which should have a way to evaluating the outcomes.

9) In our era of inter-faith dialogue, religious pluralism and ecumenism, different religious faith affiliations should cooperate in curbing the above vice of habitual betting. Moreover, the Church "family of God" perception will be of value to the young people who are seeking identity, belonging and purpose in their lives irrespective of their denomination.

10) In relation to the above, the Church needs to educate the youth that one is worth more for who they are than what they have, and should therefore approach materialism with moderation. The Church and the government should also initiate some social activities like sports and help in creating gainful jobs. Such an engagement will deter the youth from idling and thoughts of gambling.

11) The mediation theory by Boff and Boff has an implication for the pastoral group to get involved in youth ministry as a core pastoral duty. As shepherd to the flock, they will need to insert themselves in the situation and make a social analysis of what problems ails the people, and confront the findings with what the Word of God says, and a practical way forward prescribed through the praxis stage.

\section{Recommendations}

1) The study recommends that the government, non-governmental organizations and other stakeholders should come up with policies and strategies to govern betting enterprise to shield the Christian youths from engaging into betting and other forms of gambling manipulations. They should create awareness to the youths on the effect of betting and gambling and its adverse effects. This would make the Christian youths make mature decisions on involvement in betting as a form of gambling thereby guarding themselves from being hocked to the practice.

2) It also recommends that, though life is complex and occasionally troublesome, the youth should be empowered not to lose TRUST in life and living. As Fulton says, "life is worthy living."

3) The study further recommends that the government and private sector should create employment opportunities for the Christian youths in Soweto Village and elsewhere. Being in a 
paid employment will keep them busy with less time to engage in betting activities and give them some financial security.

4) The Christian youths should also be motivated to come up with creative ideas which should be enhanced to create self-employment and help to curb involvement in betting. An idle mind is a devil's workshop.

5) Radio and television adverts on betting should not be permitted to go wild. A prudent effective control in called for.

6) The Church as the "Family of God" can contribute by ensuring that the Christian youth in Soweto Village Nairobi County are equipped with the relevant values like hard work, patience endurance and love among others with a view to changing some of their attitudes and behaviours. The clergy should revamp the existing programs to include more and appropriate messages on betting. Regular seminars organized by the Church should incorporate effective approaches. Whenever possible the Christian youths should be given opportunities to showcase their talent and abilities to create their own jobs that will be able to meet their financial needs. The Christian youth therefore should emulate Jesus Christ as the best example of a liberator.

7) Agents of betting should be compelled to make explicit notices for betting items containing precise data in regard to the odds of winning and an obvious cautioning statement that highlights the potential risks related with problem gambling, and that people can make informed, sound decisions regarding betting. In case they employ undue overwhelming dirty manipulations upon the youth, they should be legally punished and compelled to make amends.

8) The agents of the Gospel like those from the RCC, Victorious Life Church and the African Israel Church Nineveh in Soweto Village have the obligation of duty to get support, guidance, inspiration and challenge from Jesus' liberating pedagogy especially that explicated in the Gospel according to Luke (4:16ff) and Prophet Isaiah (6:1-2) to help Soweto youth and those from elsewhere living the liberating pedagogy of Jesus on living full (Jn 10:10) not just surviving, readily accept Christ as the Way leading to True Life and having trust in life.

\section{Concluding Remarks}

This Research has underscored that there are serious causes of habitual betting practices Soweto Christian youth are confronted with namely: unemployment, advertisements, peer pressure, early exposure to betting and as an escape from reality together with inadequate effort by the Church evangelizers, in-effective policy by the government cum poor parenting. It has also spelt out the impact of the vice upon the youth in particular. Some of the effects of habitual betting it has come up with are: betting addiction itself becoming rampant among the youth in Soweto, early school dropout, family disruptions, job loss, suicide thoughts, rising debt levels, development of criminal behaviour and pre-mature deaths. The Research has, moreover, verified that there are triggers that make Christian youth engage in habitual betting practices as shown above; that there are effects of habitual betting among Christian youth as earlier indicated; and that agents of Good News/Gospel in their Christ-given-mandate to minister to all can play a more fruitful role curbing habitual betting among the Christian youth in Soweto Village, Nairobi County, Kenya and elsewhere if they consciously draw inspiration and guidance from Jesus' Liberating Pedagogy. As such evangelizers should talk openly on the causes and the effects of the habitual betting and betting enterprise as a 
whole among the Christian youth during the Church services or during the Mass and in every other opportune time in order to target a larger population of the Christian youth and the entire population of the community. The government and the stakeholders from the education sector and the corporate world should fund programs that spread the needed information on the adverse effects of habitual betting. The government and other stakeholders should create awareness programs that aim at promoting a culture of responsible betting among the population and other members of the society.

\section{References}

Adlaf, E. M. \&Lalomiteanu A. (2000). Prevalence and Risk Factors of Problem Gambling Among College Students, Psychology of Addictive Behaviours, 12.

Ahaibwe, G. Lakuma, C.P. Katunze M. and Mawejje, J.(2016). Socio Economic of Gambling: Evidence from Kampala City, Kampala: Economic Policy Research Centre.

Arnett, J. J.(2000). Emerging Adulthood, Amer Psychologist, 55, no. 5.

Arnold, G. Collins, P. Eadington, W. R. Remmers, P. and Ricket, T.(2003). Towards a Strategy for Addressing Problem Gambling in the U.K.: A Report to the Responsibility in Gambling Trust, London: Responsibility in Gambling Trust.

Artino, A. R. Self-Efficacy Beliefs: From Educational Theory to Instructional Practice. https://files.eric.ed.gov/ fulltext/ED499094.pdf

Australian Productivity Commission (1999), Australia's Gambling Industries, Report No. 10, Canberra: Ausinfo, .

Bandura, A.(1980). Social Foundation of Thoughts and Actions; A Social Cognitive, Eaglewood Cliffs, New Jersey: Prentice-Hall.

Binde, P.(2009). Exploring the Impact of Gambling Advertising: An interview Study of Problem Gamblers, International Journal of Mental Health and Addiction, 7, no. 4.

Binde, P. (2014). Gambling in Sweden: The Cultural and Socio-Political Context, Addiction, 109, no. 2.

Blinn-Pike, L., Worthy, S.L. and Johnman, J. N. (2007). Disordered Gambling Among College Students: A Meta Analytic Synthesis, Journal of Gambling Studies, 23, no. 2013.

Boesak, A. A.(1977). Farewellto Innocence: A Social-Ethical Study on Black Theology and Black Power, Maryknoll, New York: Orbis Books.

Boff.C. and Boff. L.(1987). Introducing Liberation Theology, Maryknoll, New York: Orbis Books.

Booth, T. and Booth, W. (1989). Growing up With Parents Who Have Learning Difficulties, London: Routledge Publishers.

Brown, R.I.F.(1987). 'Dropouts and continuers in Gamblers Anonymous: III. Some possible specific reasons for dropout'. Journal of Gambling Behavior, 3, 137-151.

Bujo, B.(1994). Ethical Dimension of Community, Nairobi: Paulines Publications, 1998.

Catechism of the Catholic Church, Nairobi: Paulines Publication Africa.

Collins, P. and Barr, G.(2009). Gambling and Problem Gambling in South Africa; A Comparative Report, Vkegurg (SA): Responsible Gambling.

Collins, P.2003). Gambling and the Public Interest, Cape Town Greenwood Publishing Group.

Cone, J.H.(2002). God of the Oppressed, Maryknoll, New York: Orbis Books. 
INTERNATIONAL JOURNAL OF ACADEMIC RESEARCH IN BUSINESS AND SOCIAL SCIENCES

Vol. 9, No. 2, Feb, 2019, E-ISSN: $2222-6990$ ๑ 2019 HRMARS

Desai, R. A.,MacieJewski, P. K. and Potenza M. V.(2015). Gender Differences in Adolescent Gambling.AnnClinn Psychiatry, 17, no. 14.

Dewar, L.(2012). Regulating Internet Gambling: The Net Tightens on Online Casinos and Bookmakers, London: MCB UP.

Dickson, L.,Derevensky, J. and Gupta, R.(2003). Youth Gambling Problems: The Identification of Risk and Protective Factors, Ontario: Ontario Gambling Research Centre.

Enderbrock, D. M. (1955). The Parental Obligation to Care for the Religious Education Within the Home, With Special Attention to the Training of the Pre-School Child, PhD Thesis, Washington DC: The Catholic University of America Press.

Federal, State, and Local Laws, Regulations, and Ordinances, National Gambling Impact Study Commission, Final Report, Washington, DC: Government Printing Office, 1999, Available at http://govinfo.library.unt.edu/ngisc/index.html

Fisher, S.(1996). Gambling and Pathological Gambling Among Casino Patrons, Plymouth: University of Plymouth.

Freire, P.(1994). Education for Critical Consciousness, New York: Continuum.

Freire, P.(1972). Education for Critical Consciousness, New York: Penguine Books.

Freire, P. (1992). Pedagogy of Hope: Reliving Pedagogy of the Oppressed, New York: International Publishing Group.

GamCare, Care Services Report, GamCare: National Association for Gambling Care, 2003.

Gerda, R. (2006). Research on the Social Impacts of Gambling: Final Report, Glasgow: University of Glasgow.

Getui, M. N. (1998). "The Family, The Church and the Development of the Youth" in J.N.K.Mugambi... (Eds.) The Church in African Christianity, Nairobi; Acton Publishers.

Government of Kenya. (2003). National Youth Policy, Nairobi: Government Printer.

Gupta, R. and Derevensky, J. (1998). Adolescents Gambling Behaviour, A Prevalence Study and the Examination of the Correlates Associated with the Problem Gambling, Journal of Gambling Studies, 14, no. 4.

Hall, S., Hall, M., Hall, N. (1996). Estimating the Prevalence Adolescents Gambling Disorders; A quantitative Synthesis and Guide Towards Standard Gambling Nomenclature, Journal of Gambling Studies, 12, no. 2.

Jacobs, D. (2000). Juvenile Gambling in North America; An Analysis of Long Term Trends and Future Prospects,Journal of Gambling Studies, 26, no. 213, 2000.

Jacobs. D. R. Marston, A. R., Singer, R. D., Widaman, K., Little T. and Veizades, J. (1989). Children of Problem Gamblers, Journal of Gambling Behaviour, 5, no. 4.

Jeremias, J. (1972). The Parables of Jesus, New York: Charles Scribner's and Sons.

Jeremias, J. (1966). Rediscovering the Parables (New York: Charles Scribner's and Sons.

Kealy, S.P. (1978). Jesus the Teacher, Denville, New Jeysey: Dimension.

Kealy, S.P.(2001). "Jesus, the Divine Teacher," in A. Radoli (Ed.) AFER, June/August, Vol. 2 nos. 3 and 4.

Kinoti, H. W.(2013). African Ethics: Gikũyũ Traditional Morality, Nairobi: CUEA Press. 
INTERNATIONAL JOURNAL OF ACADEMIC RESEARCH IN BUSINESS AND SOCIAL SCIENCES

Vol. 9, No. 2, Feb, 2019, E-ISSN: $2222-6990$ ๑ 2019 HRMARS

Kombo, D. K. and Tromp, L.A.(2006). Proposal and Thesis Writing: An Introduction, Nairobi: Paulines Publications Africa.

Korn, D. A. and Shaffer, H. J. (1999). Gambling and the Health of the Public: Adopting a Public Health Perspective, Journal of Gambling Studies, 15, no. 4.

Korn, D.(2005). Commercial Gambling Advertising: Understanding the Youth Connection Guelph ON: Ontario Problem Gambling Research Centre.

Koros, R. (2016). University Students Gambling: Examining the Effects of Betting on Kenyan University Students Behavior, University of Eldoret, International Journal of Liberal Arts and Social Sciences, 4, no. 8-9.

Kung, H. (2010). What I Believe, London: Continuum.

Langat, J. C. (2017). The Role of The Church in Evangelizing Urban Youth: A Case of St. Peters Clavers's Catholic Parish, Nairobi County, MA Thesis, Nairobi: University of Nairobi.

Laws of Kenya, Betting, Lotteries and Gambling Act Chapter 13.

Laws of Kenya. Betting Tax Act No 11 of 1963, Legal Notice No 50 of 1963.

Laws of Kenya. Betting, Lotteries and Gambling Act Chapter 131, 1991.

Leventhal, H. Safer, M.A. and Pangais, D.M. The Impact of Communication on the Self Regulation of Health Beliefs, Decisions and Behaviour, Health Education Quarterly, 10, no. 3, 1983.

Lorenz, V.C. and Yaffe, R. A. Pathological Gambling: Psychosomatic, Emotional and Marital Difficulties as Reported by the Spouse, Journal of Gambling Behavior, 4, 1988.

Mbasi, F. M.The Regulatory Regime Governing the Casino Industry in Kenya; A Need for Reforms, LLM Thesis, Nairobi: University of Nairobi, 2013.

Mbuthia, W. W. Perceived Factors Influencing Deviant Behavior Among the Youth in Njathaini Community, MA Thesis, Nairobi: Kenyatta University, 2013.

Ministry of Health. A Focus on Problem Gambling; Results of the 2006/07 New Zealand Health Survey, Wellington (NZ); Government of New Zealand, 2009.

Moltmann, J. The Crucified God, London: SCM Press, 1974.

Moltmann, J. Theology of Hope. MaryKnoll, New York: Orbis Books. 1967.

Mugenda, O. and Mugenda, A. Research Methods: Quantitative \& Qualitative Approaches, Nairobi: Acts Press, 2003.

Mwadime, A. Implications of Sports Betting in Kenya: Impact of Robust Growth of the Betting Industry, MBA Thesis, Nairobi: United States International University Africa, 201.

Nsubaga, E. H. K. Fundamentals of Educational Research, Kampala: Publication: Uganda MK Publishers, 2000.

Orodho, A. J. and Kombo, D. K. Research Methods, Nairobi: Masola Publishers, 2002.

Orodho, J. A. Elements of Education and Social Science Research Methods, Maseno: Kanezja, 2009.

Oxford Dictionaries, https;//dictionary.cambridge.org/dictionary//English//betting Retrieved 15:45p.m. 4/2/2018

Productivity Commission. Australia's Gambling Industries, Report No. 10, Canberra: AusInfo, 1999, Available at http://www.pc.gov.au/

Purdie, N., Matters, G., Hillman, Murphy, M., Ozolins, C.and Millwood, P. Gambling and Young People in Australia, Victoria: Gambling Research Australia, 2011. 
INTERNATIONAL JOURNAL OF ACADEMIC RESEARCH IN BUSINESS AND SOCIAL SCIENCES

Vol. 9, No. 2, Feb, 2019, E-ISSN: 2222-6990 C 2019 HRMARS

Rickets, T., Bliss, P., MacDonald, H. \&Rayer, C., The Extent of Gambling Among Offenders on Probation. Community Health Sheffield Trust.(2000)

Sammut, M .The Prevalence of Gambling among University Students: With a Focus on Internet Gambling, MA Thesis, Malta: University of Malta, 2010.

Shaffer, H. J. and Hall, M. N., The Natural History of Gambling and Drinking Problems Among Casino Employees, Journal of Social Psychology, 142, no.4, 2002.

Shaffer, H. J. and M. N. Hall, Estimating the Prevalence Adolescents Gambling Disorders: A Quantitative Synthesis and Guide Towards Standard Gambling Nomenclature, Journal of Gambling Studies, 12, no. 2, 996.

Sobrino, J. (1999). Jesus the Liberator: A Historical and Theological View, Maryknoll, New York: Orbis Books.

Turner, N., Spence, W. and Zangerah, M. Pathways to Pathological Gambling: Component Analysis of Variables Related to Pathological Gambling, International Gambling Studies, 8, no. 3, 2008.

Wachege, P. N. (2002). Living To Die, Dying To Live, Nairobi: Media Options.

Wachege, P. N. and Cherono, F. (2017). "Holy Spirit's Support to University Students in their Existential Challenging Life: A Case of University of Nairobi, Kenya," International Journal of Education and Research, 5, no. 11.

Wachege, P. N. and Rũgendo, F. G. (2017). " Effects of Modernization on Youths' Morality: A case of Karũri Catholic Parish, Kenya," International Journal of Academic Research in Business and Social Sciences , 7, no. 12.

Wachege, P. N. and Rũgendo, F. G. (2017). "Factors Leading to Premature Deaths of Male Youths: A Case of Karũri Village, Kĩmbu County, Kenya," IOSR Journal of Humanities and Social Science, 22, no. 7.16.

Walligo, J. M.,(1986). "Making a Church that is Truly African, in J. M. Walligo et al., Inculturation: Its Meaning and Urgency," Nairobi: St. Paul Publications.

Wambua, A. (2018). Lecture Series CRS 553: Research Methods in Religious Studies, Nairobi:

University of Nairobi.

Wanjohi, M. M. (2012). Influence of Unemployment on Youth Gambling in Nairobi, Kenya, MBA Thesis, Nairobi: University of Nairobi. 
INTERNATIONAL JOURNAL OF ACADEMIC RESEARCH IN BUSINESS AND SOCIAL SCIENCES Vol. 9, No. 2, Feb, 2019, E-ISSN: $2222-6990$ @ 2019 HRMARS 